\title{
A Computable General Equilibrium Model to Analyze Distributive Aspects in Brazil with a Trade Policy Illustration
}

\author{
Samir Cury \\ Allexandro Mori Coelho \\ Carlos Henrique Corseuil
}

\author{
EAESP, Getúlio Vargas Foundation (FGV), Brazil \\ Master in Economics (FEA-USP) \\ Institute of Applied Economic Research (IPEA), Brazil, \\ and University College of London, UK
}

\section{RESUMO}

Neste artigo é apresentado um modelo de Equilíbrio Geral Computável especificado para simular os impactos de políticas na distribuição de renda no Brasil. Para capturar os impactos distributivos, fatores de produção e instituições, como trabalho e famílias, são especificados separadamente. O modelo apresenta três blocos: mercados de produtos e fatores, e outro bloco com especificação das transferências de renda entre instituições. A especificação do mercado de trabalho incorpora recente avanço teórico que permite a determinação do desemprego involuntário no equilíbrio. No terceiro bloco, especifica-se a distribuição do valor adicionado entre fatores de produção e a redistribuição de renda entre agentes/instituições. As simulações do fechamento "parcial" da economia mostram pequena redução de bem-estar para a maioria dos trabalhadores e famílias. Verificou-se ainda que a homogeneidade do modelo vale somente com plena indexação de todos os fluxos de renda, o que tem importantes conseqüências sobre a modelagem do processo de distribuição de renda.

\section{PALAVRAS-CHAVE}

Brasil, modelo de equilíbrio geral computável, bem-estar, homogeneidade, avaliação de política econômica externa

ABSTRACT

This paper presents a Computable General Equilibrium model specified to simulate the policy impacts on income distribution in Brazil, with complex and systemic propagation methods. To capture the distributive impacts, the model adopts a design focused on the separation of production and institutional factors, as labor and households. The model has three blocks: product and factor markets, and a block

that handles with income transfers among institutions. The labor market specification incorporates a recent theoretical advance that allows the determination of involuntary unemployment in the equilibrium. The third block specifies the distribution of the value added among production factors and the redistribution of income among agents/institutions. The simulations of a partial economic "closure" show modest welfare reduction for most workers and families. Also, we checked that the homogeneity property of the model holds only with full indexation of all income transfers, which has important implications for the income distribution process modeling.

KEY WORDS

Brazil, computable general equilibrium model, welfare, homogeneity, external economic policy evaluation

JEL Classification

C68, D60, OI5, F47, FI4, O24 


\section{INTRODUCTION}

It is widely known that the Brazilian economy has historically presented one of the highest income inequality degree in the world, with a Gini index around 0.60 . It is also known that the inequality in income distribution is the main determinant of the poverty level in the country, being the average income level a secondary determinant. Since last decade, the central Government started pursuing to develop the country by implementing macro and structural reforms. Thus, it is necessary to develop an analytical framework to evaluate the distributive impacts of these policies in order to produce information to help policy makers in their design.

Having this purpose in mind, this paper has been developed using a computable general equilibrium (CGE) modeling strategy that allows for the analysis of distributive impacts of macro shocks with complex and systemic propagation methods. The model is specified to run comparative static simulations and, in an attempt to capture distributive impacts, it is adopted a specific design focused on the separation of production factors (particularly labor) and institutional components such as households, firms and governmental levels. In addition, the paper demonstrates the operation of the model through different simulations of Brazilian external (trade and finance) policies with a focus on the results related to employment, wages and household income.

The first computable general equilibrium model specified to evaluate the distributive impacts of public policies in Brazil was presented by Cury (1998), who extended the CGE model structure proposed by Devarajan et al. (1991) by increasing the number of types of labor recognized in the model and introducing another step in the nested production function, in which the different types of labor were aggregated in a composite labor factor.

Another extension was a more detailed specification of the economic institutions. The social security system was specified as a specific agent apart from the Government, the firms were divided in different types and the representative family also was highly disaggregated. Thus, with these extensions, it was possible to introduce in the base model a matrix with information on the income redistribution among the economic institutions, which allowed a better specification of the institutions' income formation process.

Barros et al. (2000) evaluated the distributive impacts of the external (trade and capital flows) liberalization process in Brazil using an extended version of the model specified by Cury (1998). This extension was characterized by the introduction of a more detailed specification of the labor market, which was completed in the new model presented in this paper. 
The new specification of the labor market, presented here, is characterized by the introduction of wage curves, as proposed by Blanchflower and Oswald (1990, 1994), empirically estimated for the Brazilian economy. ${ }^{1}$ Another advance in relation to the previous model was the incorporation of a newer database that allowed the recognition of a larger number of sectors in the model, the 42 sectors listed in the Brazilian National Accounts. Other empirical advances were the incorporation of the Armington elasticities for the tradable sectors and the wage curve parameters, which, for the first time, were estimated for the Brazilian economy. A final empirical advance is the integrated usage of a household survey (PNAD) together with a household revenue-expenditure survey $(\mathrm{POF}){ }^{2}$

Recently, the evaluation of the distributive impacts in Brazil due to trade policies has received attention in the CGE modeling literature. Hertel et al. (2003) and Harrison $e t$ al. (2003) evaluated the impacts of different bilateral and multilateral trade agreements on poverty in Brazil, using multi-country CGE models, in which the Brazilian representative family is disaggregated in several types. ${ }^{3}$

The model presented in this paper is divided into three blocks: product market, factors market (essentially labor), and one block about income transfers among institutions. The first block assumes a general neoclassical equilibrium for most markets in which the agents respond to relative prices changes as a result of the maximization of profits or utility by determining levels of production and consumption. This specification is very similar to one adopted by Devarajan et al. (1991), that has recently proven be popular with CGE modelers.

The labor market block incorporates a recent theoretical advance, the wage curve, that allows for the determination of involuntary unemployment in the equilibrium. Traditionally, CGE models follow the classical labor market story, in which jobs are available for everyone searching for employment. As this result does not seem to reflect the way the labor market operates in most countries, ${ }^{4}$ advances have been discussed in the literature and incorporated in the model. ${ }^{5}$

1 Further details on wage curves will be presented in section 2.

2 PNAD - Pesquisa Nacional por Amostra de Domicílios; POF - Pesquisa de Orçamento Familiar. Both of 1996, the model's base year.

3 The usage of multi-region CGE model is required in their case due to the kind of policies they are evaluating.

4 Blanchflower and Oswald $(1990,1994)$ present supporting evidence of this fact for 15 countries and also present a survey on other researches that found similar results.

5 A more enhanced representation of the labor market in CGE may be found in Bovenberg et al. (2000). 
The third block includes information on the distribution of the value added in the productive process among the production factors, as well as its redistribution among agents/institutions considered in the model; these redistribution mechanisms was not present in Devarajan et al. (1991).

In the literature on the application of general equilibrium, the model used in this paper may be considered as a development of the "CGE-RH Approach", in which the focus is on the disaggregated specification of the agents. (Bourguignon et al., 2002). Moreover, the attention given to transfer flows among institutions places the model in the direction of a "Tax Model", focusing on the redistribute role of the public sector. (Devarajan and Hossain, 1998). ${ }^{6}$

The paper is structured in seven sections. After this introduction, the following three sections show each one of the 3 main model blocks discussed above. In the fourth section, an important attribute of CGE type models will be discussed showing the homogeneity of degree zero in prices; we describe the procedure adopted to guarantee the maintenance of this property in the model besides justifying the reason for this concern. Section five contains the description of the simulation results and last section concludes the paper.

\section{THE PRODUCT MARKET}

\subsection{Product Supply}

Foreign product supply is modeled as being totally elastic, ${ }^{7}$ while domestic supply is represented in a more elaborated way, through a nested production function, which considers three types of inputs: labor, capital and intermediate inputs. This production function form is identical for all sectors and can be obtained in three stages. ${ }^{8}$

In the first step, the amounts of the several types of existing labor $\left(F_{1}\right)$, given by the first order firm's profit maximization conditions, ${ }^{9}$ are combined in a composite labor

6 Currently, there is a strong emphasis on the combined usage of different structures (macro models, CGE and micro simulation). Barros et al. (2000a) applied the impacts of some variables of the CGE model to similar variables of a micro database for calculating poverty and inequality indicators in Brazil. For further discussion on this methodology, see Bourguignon et al. (2002).

7 In this sense, Brazilian demands for imported goods are fully satisfied without facing external supply constraints.

8 The model represents the 42 sectors of activities listed in the 1996 Brazilian National Accounts, whose tradable sectors are presented in the sixth section of the paper.

9 See bellow, equation 6 in section 2 . 
$(L d)$ for each sector $(i)$, using for this purpose a Cobb-Douglas function with constant returns to scale. ${ }^{10}$ The labor types recognized in the model are: 11 -unskilled informal, 12-skilled informal, 13-formal with low skill, 14-formal with average skill, 15-formal with high skill, 16-low skilled public servant and 17-high skilled public servant, which are aggregated in the following form:

$$
L d_{i}=\prod_{1} F_{i l}^{\beta_{i l}}
$$

where $\beta_{i l}$ is the share of each type of labor.

In the second step, aggregated labor $(L d)$ and capital $(K)^{11}$ are associated using a constant elasticity of substitution (CES) function to obtain the sector $i$ 's production values $\left(X_{i}\right)$ such as:

$$
X_{i}=a_{i}^{D}\left[\alpha_{i} L d_{i}^{\rho_{i p}}+\left(1-\alpha_{i}\right) K_{i}^{\rho_{i p}}\right]^{1 / \rho_{i p}}
$$

where $a_{i}^{D}$ is the CES shift parameter, $\alpha_{i}$ is the labor share in the sector's $i$ production value and $\rho_{i p}$ is the elasticity of substitution between capital and labor.

Finally, in the third step, various intermediate inputs levels, (INT $\left.{ }_{i}\right)$, can be obtained, based on a Leontief production function (e.g., fixed proportion to sector $j$ 's total product, $\left.X_{j}\right):^{12}$

$$
I N T_{i}=\sum_{j} a_{i j} X_{j}
$$

where $a_{i j}$ is the technical coefficient of input $j$ in sector $i$.

However, this output is not entirely offered to the domestic market. Producers react to the relative price of the domestic market vis-à-vis the international market. Thus, it is assumed that the producers do not specialize in only one market, i.e., the domestic production is totally divided with imperfect substitution among products sold to the domestic market and products destined for the outside market. The chosen functional form presents constant elasticity of transformation (CET) and assumes the following form in the model:

$$
X_{i}=a_{i}^{T}\left[\gamma_{i} E_{i}^{\left(\rho_{i t}+1\right) / \rho_{i t}}+\left(1-\gamma_{i}\right) D_{i}^{\left(\rho_{i t}+1\right) / \rho_{i t}}\right]^{\left(\rho_{i t}+1\right) / \rho_{i t}}
$$

10 This means that an identical increase of every type of worker results in an identical increase of the aggregate worker.

11 The model closure adopted in the simulations determines that the sectoral levels of capital are fixed.

12 It is worth mentioning that Devarajan et al. (1991) makes use only of the first and third steps, by combining capital with labor and value added with intermediate inputs, in this order. 
where $X_{i}$ is sector $i$ 's total domestic production, $E_{i}$ is the volume exported by sector $i$, and $D_{i}$ is the domestic output of sector $i$ sold in the internal market. $a_{i}^{T}$ and $\gamma_{i}$ are parameters of the model and $\rho_{i t}$ is the elasticity of transformation. ${ }^{13}$

\subsection{Demand for Products}

Families

Families are classified into eight categories, according to per capita household income, level of urbanization and household head characteristics. The family types considered are: fl-poor urban families headed by active individual, f2-poor urban families headed by non-active individual, f3-poor rural families, f4-urban families with low average income, f5-urban families with average income, f6-rural families with average income, f7-families with high average income, f8-families with high income.

This separation yields more precision in the classification of the families by the degree of dependency to the various sources of household income, including the remuneration of production factors, social security monetary benefits, and net income from financial assets.

As for the behavior of the families, we assume that they choose their consumption levels to maximize their utility subject to a budget constraint. ${ }^{14}$ In the current version of the model, we use a Cobb-Douglas functional form (similar to the production function presented above), whose arguments are the commodities available for consumption.

The goods demanded by families and firms, on the other hand, are not only those domestically produced, since these agents also demand goods from abroad. Following Armington (1969), we assume that goods are classified according to their source (domestic or external) and that consumers consider them as imperfect substitutes, while their utility is measured (in product quantity) by a function with a constant elasticity of substitution (CES) with the following form:

$$
Q_{i}=a_{i} c\left[\delta_{i} M_{i}^{\left(\rho_{i c}-1\right) / \rho_{i c}}+\left(1-\delta_{i}\right) D_{i}^{\left(\rho_{i c}-1\right) / \rho_{i c}}\right]^{\rho_{i c} /\left(\rho_{i c}-1\right)}
$$

13 There are no empirical estimates of Brazilian export elasticities using a CET structure for a highly disaggregated sectoral specification. Therefore, it was adopted the same procedure used in Cury (1998, p. 112 113), which departed from the elasticities estimated by Holand-Holst, Reinert and Shiells (1994) to the American economy.

14 Actually, this utility maximization can happen along the consumers' lifetime. From the point of view of most practical applications, the maximization is on the goods and services available in a given period. 
where $M_{i}$ indicates the imported volume of $\operatorname{good} i$, and $D_{i}$ is the consumption of the domestic good $i . a_{i} c$ and $\delta_{i}$ are parameters and $\rho_{i c}$ is the elasticity of substitution between $D_{i}$ and $M_{i}$, whose values were taken from Tourinho et al. (2002), who estimated these Armington elasticities for the same sectors considered in the model. Finally, $Q_{i}$ is an indicator of the utility derived from the consumption of good $i$, but it also can be interpreted as a quantity of a hypothetical composite good, which adds imported and domestic goods. This composite good is what the consumers would demand.

There is also a demand for domestic goods in the international market where agents react to changes in relative prices as well. In a form analogous to that specified for import demand, the demand for exports arises from a CES utility function which represents the imperfect substitution between Brazilian products and products from the rest of the world.

Firms

Firms contribute in two ways for product demand. First, they satisfy their requirements of intermediate inputs necessary to the productive process. This demand is determined by the technical coefficients from the input-output matrix.

Due to the static nature of accumulation in the capital market, investments are important for product demand. As for the case of consumption, the investment is characterized as the purchase of certain goods. In this case, investment would be a type of final consumption undertaken by firms. Savings represent this amount of resources, and we assume that a share of it corresponds to investment in stocks of finished goods, while the remaining share corresponds to the available amount required to purchase the final goods that must be used to expand production. The first share is defined based on a fixed proportion of the sector output, while the second share is distributed exogenously among the different sectors, reflecting information from the input-output tables (goods by sector of origin) and the matrix of sectoral composition of capital (goods by sector of destination and origin).

As mentioned before, it is being considered that the investment goods are being produced but not considered as increments of capital stock. Thus, the model closure is closer to a medium-run type: constant capital stock, price flexibility and existence of involuntary unemployment in equilibrium.

\section{Government}

We assume that government consumption (GC) is derived from maximization of a Cobb-Douglas utility function subject to the budgetary restriction corresponding to the total expenditure that is fixed according with the total amount registered for the base year. 


\section{THE LABOR MARKET}

As we have already seen, labor is modeled as a production factor used by firms. This factor is classified into 7 types, reflecting different forms of insertion in the labor market (contract status) and schooling. ${ }^{15}$

We assume that the firms aim at maximizing profits taking the price of inputs, production factors and output as given. The firms also consider the technological constraints imposed by the production function specified before. Therefore, as a result of this maximization, the wages for each type of labor equalize their respective marginal productivity so that a demand curve for each type of labor is defined by: ${ }^{16}$

$$
P_{i} \partial X_{i} / \partial F_{i l}=W_{i l}
$$

As mentioned before, our alternative to incorporate involuntary unemployment in the equilibrium consists of interacting the demand for labor with the wage curve. This curve is a statistical regularity or empirical 'law' of economics originally reported by Blanchflower and Oswald $(1990,1994)$ that is described by a negatively sloped curve linking the employees' wages to the unemployment rate in their region (or industry). The causality is thought to run from the unemployment rate to wages and the curve emerged from microeconometric earnings equations estimation on large and comparable data sets for fifteen developed countries. ${ }^{17}$

The wage curve implemented in the model represents the negative relation between the unemployment rate $\left(U_{l}\right)$ and the wage level $\left(W_{l}\right)$ for the each type of labor $l$ in Brazil, and that can be described by the following equation: ${ }^{18}$

$$
\ln W_{l}=\alpha_{i}-\beta_{l} \ln U_{l}
$$

15 The labor treatment that follows is applied for the 5 types of private labors. The 2 types of public workers follow the traditional labor market closure of CGE models with either wage or employment being fixed. Therefore, there is no substitution between public servants and the private kinds of labor, in the sectors where there is no public companies. In the sectors where public and private firms coexist, the changes in the public-private composition of labor are related to the changes in the public-private composition of the sectoral representative firm.

16 The derivative of the profit function in relation to the demanded quantity of each factor must be equal to the factors' price (first order condition).

17 The estimated curve held after controlling for workers' personal and demographic characteristics, for regional characteristics, and for macroeconomic and other aggregate influences, and presented very similar curvature of the function in each of the fifteen countries in which the curve has been found. Bhalotra (1993) and Hoddinot (1993), apud Blanchflower and Oswald (1994), found similar results for India and Cote d'Ivoire, respectively.

18 Another specification of the wage curve that already was incorporated to interregional CGE models. This specification captures the relationship between regional unemployment rates and regional wage levels. See the specification of the AMOS model (see Ferguson et al., 2003). 
Blanchflower and Oswald (1994) also present the theoretical foundations that justify the existence of wage rigidity, that is, basically efficiency wages or union bargaining. According to the first theory, the firm tends to motivate an efficient behavior by means of attractive wages. However, when the unemployment rate is high, the worker feels threatened of losing his job and tends to be naturally efficient and the firm does not need to offer an attractive wage. In an alternative way, firms may feel pressured to raise wages when unemployment is low, as the bargaining power of workers increases under this situation.

In sum, we can interpret the wage curve as a firm's wage determination policy that takes into consideration the competition among workers to occupy a job vacancy. When this competition is high (high unemployment rate), the firm can offer a relatively low wage. The sensitiveness of this movement is given by the parameter $\beta$, whose values were taken from Reis (2002), who presents their econometric estimations for the Brazilian case.

The form in which the wage curve operates in the labor market equilibrium determination can be visualized in the figure below. ${ }^{19}$ Point $E_{0}$ represents the full employment equilibrium in a market affected only by supply $\left(L^{o}\right)$ and demand $\left(L^{d}\right)$. With the introduction of the wage curve $(S)$, the equilibrium levels of employment and wages is determined by $E$, the intersection point between the demand curve and the wage curve. The wage level defined by $E$ ' does not correspond to the labor supply, and the difference is the excess supply of labor that corresponds to the unemployment level in the economy. FIGURE 1 - EQUILIBRIUM IN THE LABOR MARKET FOR A GIVEN TYPE OF
LABOR

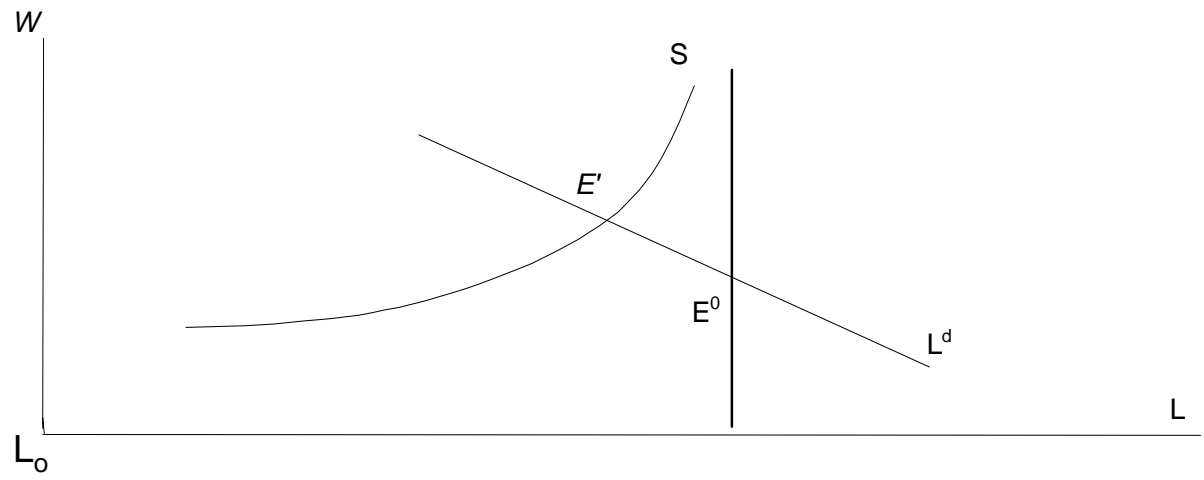

19 In order to represent the relation in axis $\mathrm{L}, \mathrm{W}$ we must have in mind that $U=\left(L^{0}-L\right) / L^{0}$. 
Note that the labor market closure is not formulated by sector, but rather by type of labor. $^{20}$ Therefore, the adjustment mechanism is from the aggregate to the sectoral level. After an economic shock, first, we have the definition of the aggregate levels of employment, wages and unemployment for each type of labor by the interaction of their aggregate demand, aggregate supply and wage curves, as explained earlier. To define the employment and wage levels in each sector, it is necessary to assume an additional behavioral rule in the labor market.

The labor market specification is complemented, therefore, by assuming that the wages of a given type of worker are differentiated by sector in the model, which implies, in practical terms, in sectoral imperfect segmentation in the labor market (for example, a formal worker with average qualification employed in the mechanic/automobile sector receives a larger wage than a worker with similar schooling degree and contract status would receive in the clothing sector) ${ }^{21}$ In this sense, there is imperfect mobility of workers among sectors and, thus, the sectoral wage differentials will not be eliminated, that is the wage equalization among sectors can not be achieved, by means of the migration of workers from sector(s) paying low wages to sector(s) paying higher wages.

The mechanism used in this process is the inclusion of an exogenous variable for relative wage differentials among the sectors. Thus, from the average wage for each type of labor $\left(w_{l}\right)$, we can determine the wage of each kind of worker in each sector $\left(w_{l i}\right)$. With this information, by means of a sector and labor type specific demand curve (equation 6), we can also determine the sectoral employment level of each type of labor $\left(F_{i l}\right)$, which are aggregated by a Cobb-Douglas function (equation 1 ) to define the sector $i$ 's composite labor. ${ }^{22}$

\section{THE MECHANISMS OF INCOME TRANSFER}

In this block of the model, we take into consideration the formation of income flows received by families, firms, government, and the rest of the world. This process encompasses two parts: the definition of the distribution of the value added in the pro-

20 The same applies for labor supply.

21 The hypothesis implicit in the adopted mechanism is that workers with similar observed productive characteristics (schooling and contract status) are paid in a different way according to their sector of employment/occupation. The idea is to capture the fact that, although the mentioned similarities, the workers have another characteristics such as profession type and sector specific training/qualifications that do not permit their free mobility to all other sectors but also do not completely constrain their mobility to some other sectors. Pinheiro and Ramos (1995) have not only proven this fact but also demonstrate that it is stable along the time.

22 In this sense, the substitution of a specific type of worker, the change of its share in the sectoral aggregated labor, depends of the changes in the amounts $F_{i l}$. 
ductive process (primary income distribution) and the transfers among the mentioned agents (secondary income distribution).

The first part consists in attributing to firms the remuneration of capital and to workers the remuneration of labor. It is worth mentioning that the model considers two types of firms: small (self-employed people) and large (other firms). In each sector, the payments to capital are distributed to the firms according to the initial proportion in the total earnings of capital. Thus, the large firms receive a higher share of this payment, while the small firms receive the remaining parcel.

The distribution of the earnings of the seven types of labor to the eight types of families is made according to the initial distribution of these workers by families. The share of income of each type of worker that goes to family $h$ is given by the proportion of this type of labor that is in this type of family $\left(\varepsilon_{h l}\right)$. Families also receive the remuneration of capital transferred by firms (large and small), $Y K$. The distribution among each type of family is given by the family $h$ 's proportion in each of these income flows (matrix $\left.\varepsilon_{h k}\right)$.

Besides these remunerations, the net remittances from abroad $\left(R_{E h}\right)$, adjusted by the exchange rate $(R)$, and the share of transfers made by the government and directed to the families $(T G)$, complete the determination of the household incomes. This last transfer is made in two alternative ways: as payment of benefits in the form of direct income transfers, ${ }^{23}$ and as other transfers from the government to families (essentially domestic debt interest). The sharing of these resources among the different types of families in the model is fixed according to the proportion observed in 1996 ( $\theta_{h t}$ for the government transfers). Therefore, the income of the family $b$ can be represented as follows:

$$
Y_{h}=\varepsilon_{h l} W_{l}+\varepsilon_{h k} Y K+\text { pindex } \theta_{h t} T G+R \cdot R E_{h}
$$

Note that the government plays a very important role in the process of determination of secondary income. Besides the transfers to families mentioned above, the government also directs a share of its transfers to firms ${ }^{24}$ under the form of interests on the domestic debt and consumes products in the way described in the previous section. As in the case of families, the sharing of government transfers by type of firms follows the proportions observed in the base year $\left(\theta_{k}\right)$. Finally, the government also transfers resources abroad $(G E)$ and government expenditures can be represented as follows:

23 These transfers include the social security benefits as well as other programs such as unemployment benefits, income transfer social programs and other cash benefits.

24 The same applies for labor supply. 


$$
G G=\sum_{i} C G_{i}+\text { pindex }\left(\theta_{h t}+\theta_{k}\right) \cdot T G+R \cdot G E
$$

To face all the mentioned expenditures, the government relies on three types of collections. First, there are direct taxes levied on firms and families that correspond to a fraction of these agents' income ( $\phi_{h}$ and $\phi_{k}$, respectively). There are indirect taxes levied on domestic and imported goods, which are proportional to the produced $(X)$ and imported $(M)$ amounts. The government also receives transfers from abroad (gfbor) and, finally, there is the balance of the social security system $(S O C B A L) .{ }^{25}$ Thus, the Government total revenue is given by:

$$
R G=\sum \phi_{h} \cdot Y_{h}+\sum \phi_{k} \cdot Y \cdot K+\sum \xi_{j} \cdot X_{i}+\sum \kappa_{i} \cdot M+R \cdot P R+S O C B A L
$$

An eventual lack of government resources is defined as a government deficit that, together with private (from firms and families) and foreign savings, defines the amount of resources spent in the form of investments.

\section{CHECKING THE HOMOGENEITY HYPOTHESIS}

Due to the particularities of this model that tries to explore the complex income flows among the institutions, the usual property of homogeneity of degree zero in CGE models can no longer be valid, if at least one transfer flow is not indexed by the price index. In practical terms, this property means that the real variables are immune to a homogeneous shock in prices. $^{26}$

By intuition, this result arises from the fact that relative prices remain unchanged. As the reaction of agents in both markets (goods and factor) in this type of model is a function of relative prices, there are no reasons to believe that agents will change their behavior after a shock that changes all prices in the same proportion.

The model expands substantially the number of redistributive transactions. In that way, it is necessary to check the validity of the homogeneity restriction due to its importance for the results interpretation. From a theoretical point of view, the solution would

25 In fact, social security is treated as an agent apart from the Government in the model, not only because of the considerable amount of resources that it handles in Brazil, but also because of the contributions that it applies on either the company's income (here again in a different form), or on the installments of the added value of labor.

26 Ginsburgh and Keyzer (1997) puts the theoretical issue on homogeneity in the following form: "In any problem of optimization involving producers and consumers, the substitution of vector $p$, the equilibrium price, by $\lambda$, with a $\lambda$ scalar greater than zero, results in the nominal variation of the producers profit, but does not alter their decision; on the other hand, for consumers, both sides of the budget restriction are modified, without varying the set of possible options. Therefore, as the preferences are not modified, the optimal decision is not affected." 
be to index all the income transfers with a general price index. Thus, from an operational point of view, we index the governmental direct transfers to the remaining resident people in the country with the model's price index, and with the nominal exchange rate all the income flows with the rest of the world.

Nevertheless, an empirical test is necessary, as the complexity of the operational details of our extensions could have yielded deviations from the theoretical result. Thus, from an empirical point of view, the checking of this hypothesis is made by changing the model's numeraire-price. In our specific case, this simulation took the form of doubling the exchange rate and then checking the effects on prices and quantities.

Actually, the results of this simulation indicate that there was no change in the set of real variables (quantities; see Appendix 1). For the prices, there was a complete duplication and, consequently, in all nominal magnitudes in the model.

Thus, we have opted for this model specification that attends the homogeneity property. The counterpart of this procedure is to assume that all the income flows that we have modeled are perfectly indexed; a phenomenon that may not occur in the real world due to information problems and/or distributive conflicts.

\section{SIMULATING A TRADE POLICY SHOCK}

The impacts of alternative trade policies in the Brazilian economy have largely been evaluated by the usage of CGE models, focusing on the analysis of the impacts on production and employment, given the fact that the country has been involved in discussions related to trade block agreements and broader negotiations under the WTO negotiations. ${ }^{27}$

The main exogenous variables, whose values are, in practice, defined by the Brazilian trade policy, are the import tariffs. In 1990, the trade liberalization process was accelerated and so, in order to not simulate an arbitrary policy, we will simulate a partial "closure" of the Brazilian economy by imposing the 1990's import tariff levels. Then, the simulation results can be interpreted as being the families' welfare changes in the absence of the tariff liberalization process observed from 1990 to 1996.

The objective of this simulation is to evaluate which would be the distributive impacts in Brazil at 1996 (base year) if the economy present the tariff structure of 1990, which is presented in Table 1 below:

27 Bonelli and Hahn (2000) and Castilho (2002) present surveys of these studies. Other recent study that has evaluated these impacts is Haddad et al. (2002). 
TABLE 1 - AVERAGE NOMINAL TARIFF (\%)

\begin{tabular}{lcc}
\hline Sector & 1990 & 1996 \\
\hline Agriculture and Livestock & 5,9 & 7,3 \\
Mineral Extraction & 9,6 & 3,7 \\
Coal and Oil Extraction & 3,3 & - \\
Non-Metallic Minerals & 31,5 & 10,5 \\
Metallurgy & 14,5 & 7,8 \\
Non-Iron Metallurgy & 17,6 & 8,8 \\
Other Metallurgic Products & 34,8 & 15,9 \\
Machines and Tractors & 37,2 & 15,5 \\
Electrical Material & 44,1 & 17,2 \\
Electronic Equipment & 40,6 & 15,6 \\
Automobiles, Trucks and Buses & 78,7 & 52,4 \\
Parts and Other Vehicles & 37,4 & 16,1 \\
Wood and Furniture & 25,4 & 11,0 \\
Paper and Publishing & 23,6 & 10,3 \\
Rubber & 46,6 & 12,5 \\
Chemical Elements & 24,8 & 6,5 \\
Oil Refinery & 19,4 & 4,1 \\
Other Chemical Products & 21,8 & 7,8 \\
Pharmaceuticals and Perfumes & 31,5 & 8,0 \\
Plastic Items & 39,0 & 15,2 \\
Textiles & 31,8 & 16,3 \\
Apparel & 51,1 & 19,8 \\
Shoes & 29,6 & 15,3 \\
Coffee Industry & 28,9 & 12,0 \\
Vegetal Products Processing & 34,6 & 12,0 \\
Animal Slaughter & 19,7 & 9,2 \\
Dairy Products & 32,7 & 18,9 \\
Sugar Industry & 25,7 & 16,0 \\
Vegetal Oils & 16,6 & 13,1 \\
Other Food Products & 45,0 & 13,0 \\
Miscellaneous Industries & 41,6 & \\
\hline Simple Average & 30,5 & \\
\hline & & \\
\hline
\end{tabular}

Source: Kume et al. (2000)

In relation to the role of these variables in the Brazilian trade policy, it is worth mentioning that this policy covers a range of instruments that goes beyond the tariffs. There is a series of non-tariff barriers that might have substantially affected the country's in- 
ternational trade flows. ${ }^{28}$ In this sense, the simulated policy is the reconstitution of the tariff structure and not the rebuilding of the complete trade barriers structure prevailing in 1990, whose impacts would possibly be larger than in the previous case, since the non-tariff barriers in this year were higher than in 1996.

Another feature of the implemented simulations is that the results reflect the internal impacts from the unilateral tariff policy change, which are, at most, a little different from the ones that would be obtained with a multi-country model, which also take in account the "external side" of these impacts. This happens because in a single-country model the external regions are not modeled, in the sense that the model database does not present their economic matrices, and, therefore, the feedbacks from them are not captured.

Since Brazil is a small country, even though the effects presented here do not capture all the impacts, they capture the all the internal impacts, which correspond to the stronger effects and to the larger part of the total impacts. In this sense, the changes in the Brazilian economy due to the policy simulated in this research would not cause significant effects in the rest of the world, especially in the case of only Brazilian unilateral tariff liberalization.

Thus, also, we believe that the single-country model employed is well-suited to analyze the impacts of the Brazilian external tariff liberalization and, even the "partial" closure scenarios are stylized, they offer a useful benchmark for assessing the potential distributive impacts. Before we comment on the results, it is worth mentioning how the simulated policy affects the labor market indicators in the model. In general, the tariffs rise affects the productive structure that, by its turn, affects the demand for the different types of workers. The transmission mechanisms present in these changes are shown in Box 1.

BOX 1 - TRANSMISSION MECHANISMS OF THE CHANGE IN THE TARIFF ON THE DEMAND FOR LABOR

\begin{tabular}{|l|l|l|l|}
\hline$\uparrow$ Tariff & $\uparrow$ Demand for Domestic Goods (a) & $\uparrow$ Labor Demand & $\begin{array}{l}\uparrow \downarrow \text { Labor } \\
\text { Demand }\end{array}$ \\
\hline & $\begin{array}{l}(\uparrow \downarrow) \text { Resources Available for the } \\
\text { Government }\end{array}$ & $\uparrow \downarrow$ Government Consumption (b) & \\
\cline { 3 - 3 } & & $\uparrow \downarrow$ Private Consumption via Government Transfers (c) & \\
\cline { 3 - 4 } & & $\uparrow \downarrow$ Investment via Government Savings (d) & \\
\hline
\end{tabular}

28 Among the historically more relevant non-taxable barriers, there are the imposition of quotas, the specification of minimum prices for imported goods and the prior licensing, with complex bureaucratic procedures. 
The higher tariffs, on one hand, induce consumers to substitute imported goods by domestic goods because they become relatively cheaper than the former ones. On the other hand, the external demand for domestic goods can fall due to possible valuation of the real exchange rate and price increase of imported inputs.

At the other source of demand, the government can either increase or decrease its revenue collections with the tariffs rise, depending on the fall in consumption of imported goods vis-à-vis the larger tax levy per product. In this case, the government is forced to increase either its expenditures or its savings.

In this case, the demand for domestic goods would be altered. With changes in expenditures, government consumption and the level of transfers to families would also change. In the case of changes in savings, the amount available for savings would change, that in the model would mean a change in the demand for goods. Therefore, the effect on the demand for labor is unknown a priori.

The demand for each type of labor, by its turn, will also depend on which sectors have benefited the most from the import substitution and on which sectors have been affected the most by the change in government consumption or family transfers. Based on the information displayed in Box 1 , we can say that the effect on labor demand depends on a combination of the impacts (a), (b), (c) and (d).

It is important to stress the need of an adequate interpretation of the simulation results so that they can be considered for policy evaluation. It is being evaluated only the distributive effects of the reconstitution of the 1990's tariff structure, in environments without and with the changes in the external capital flows, that is, if these were the only changes occurred in the country. Obviously, the Brazilian economy experienced other macroeconomic and institutional changes during the considered period, as the reduction or complete removal of non-tariff barriers, technological change, labor productivity increase and the Real stabilization plan and the effects of Mexican financial crises. In this sense, the comparison of the simulated impacts with observed facts could not produce accurate conclusions, because these facts resulted from the interaction of many changes in the country, of course, including the simulated ones. 


\subsection{Results and Analysis of Tariff Rise Simulation}

TABLE 2 - SIMULATING AN IMPORT TARIFFS RISE

\begin{tabular}{llcccc}
\hline \multicolumn{5}{c}{ Percentage Change in Employment } & \\
\hline & Total & Formal & Informal & Skilled & Unskilled \\
\hline Total & $-0,405$ & $-0,413$ & $-0,577$ & $-0,137$ & $-0,536$ \\
Traditional Tradable & $-2,240$ & $-1,821$ & $-2,713$ & $-0,948$ & $-2,407$ \\
Modern Tradable & 0,357 & 0,330 & 0,485 & 0,173 & 0,414 \\
Non-Tradable & 0,117 & $-0,070$ & 0,337 & $-0,090$ & 1,594 \\
\hline
\end{tabular}

Table 2, above, reports the impacts on the level and the structure of employment following the tariff shock simulation. The table reveals that the reaction to the import tariff rise would be a decline of less than $0.5 \%$ in aggregate employment. Although relatively small, this change points to a negative balance in the generation of employment, and as such, this result contradicts those who support policies that protect the domestic firms.

Concerning to the grouped sectors above, we notice that the negative effect on aggregate employment is due to the decline of employment in traditional tradable sector (see the first column of the table). In our interpretation, with lower imports there will be a pressure to overvalue the exchange rate that will tend to make exports more expensive, which will be reinforced by an increase in input prices used to produce exported goods. The sectors in which exports are more sensible to price changes are the most traditional ones. Thus, by exporting less, there would be a tendency for these sectors to produce less and, therefore, to employ less workers.

Regardless the economic sector and considering only the type of labor, the results are more homogeneous in the job contract status dimension (type of insertion in the labor market), since both will tend to present modest reduction in the employment level. On the other hand, one can notice an employment reduction concentrated among the unskilled workers.

TABLE 3 - SIMULATING AN IMPORT TARIFFS RISE

\begin{tabular}{|c|c|c|c|c|c|c|c|}
\hline \multicolumn{8}{|c|}{ Percentage Change in the Average Wage } \\
\hline & Worker 1 & Worker 2 & Worker 3 & Worker 4 & Worker 5 & Worker 6 & Worker 7 \\
\hline Total & $-0,673$ & $-0,522$ & $-0,483$ & $-0,724$ & $-0,007$ & $-0,587$ & $-0,76$ \\
\hline
\end{tabular}

Note: 11- unskilled informal; 12- skilled informal; 13 - formal with low skill; 14 - formal with average skill; 15 - formal with highly skilled; 16 - low skilled public servant; 17- highly skilled public servant. 
As regards the wages, it is worth remembering that, in the model, the sectoral wage differentials are rigid. Thus, the wage structure can only react to the type of labor. As a consequence, we report, in Table 3 , the changes in real wages for each type of worker without any sector desegregation.

Note that the general effect is a real wage fall. Among the informal workers, the main losers would be the less skilled, and for the formal ones, the main losers would be the unskilled and the average skilled. The formal high-skilled workers present a differentiated result since this type of workers does not seem to have their real wages affected, actually, becoming beneficiary of this policy and confirming the same type of behavior observed for the level of employment. The high reduction of public servants' remuneration is due to the fact that their employment levels are fixed in the model; thus, the total effect goes to their salaries.

TABLE 4 - SIMULATING AN IMPORT TARIFFS RISE

\begin{tabular}{|c|c|c|c|c|c|c|c|}
\hline \multicolumn{8}{|c|}{ Percentage Change in Household Income } \\
\hline Family 1 & Family 2 & Family 3 & Family 4 & Family 5 & Family 6 & Family 7 & Family 8 \\
\hline$-0,512$ & $-0,229$ & $-0,452$ & $-0,458$ & $-0,478$ & $-0,428$ & $-0,5$ & $-0,462$ \\
\hline
\end{tabular}

Note: fl - poor urban families headed by active individuals, $\mathrm{f} 2$ - poor urban families headed by nonactive individuals, f3 - poor rural families, f4 - urban families with low average income, f5 urban families with average income, f6 - rural families with average income, f7 - families with high average income, $\mathrm{f} 8$ - families with high income.

Table 4 shows that all types of households have their incomes affected by the import tariff rise. The results show income falls that range between $-0,229\left(f_{2}\right.$ - poor hou-

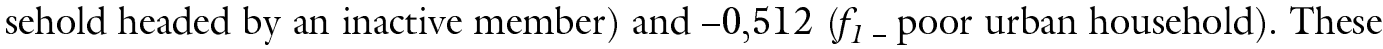
results demonstrate two factors: the least affected household is the one with a lower dependency on labor income, and the largest fall is observed for the poorest type of household.

In the Brazilian economy, the labor income has a large weight in the generation of the household income. Nevertheless, income transfers have an important participation, mainly for the poor households through the social security benefits and the social programs of direct transfers, and, in the case of rich households, through interest rate transfers and retirement pensions received from the public sector.

Therefore, despite the fact that the results partially reflect these characteristics, they are limited by the identical indexation of these transfers, which smoothes possible larger adjustments in the household income. 


\subsection{An Alternative Simulation With Trade Policy and Capital Flow Shocks}

In this alternative simulation, we reproduce the former simulation adding a different value for external direct investment through the net flow of capital account. In this way, we implemented the values verified in $\mathbf{1 9 9 0}$ for the tariffs on imports and the external direct investment level, which was $34 \%$ lower than in the base year. The simulation results can be interpreted as being the families' welfare changes in the absence of the external liberalization process. ${ }^{29}$

As an answer for this combined movement, the trade deficit would have a forced reduction of $56 \%$ due to the fall of imports (around $10 \%$ ) and the increase of exports (around 3,5\%). ${ }^{30}$ Despite the exogenous implementation of the new capital flow, we believe that this hypothesis is very consistent with a closed economy movement that reduces the level of capital inflows, as verified in the Brazilian economy before the recent process of external liberalization.

TABLE 5 - SIMULATING AN IMPORT TARIFFS RISE AND CAPITAL INFLOW REDUCTION

\begin{tabular}{lccccc}
\hline \multicolumn{7}{l}{ Percentage Change in Employment } \\
\hline Total & Formal & Informal & Skilled & Unskilled \\
\hline Total & $-0,982$ & $-0,857$ & $-1,185$ & $-0,671$ & $-1,092$ \\
Traditional Tradable & 0,767 & 0,913 & 0,628 & 1,887 & 0,657 \\
Modern Tradable & 1,267 & 1,298 & 1,065 & 1,233 & 1,284 \\
Non-Tradable & $-1,776$ & $-1,604$ & $-2,077$ & $-1,115$ & $-2,075$ \\
\hline
\end{tabular}

Table 5, above, shows the employment variations. There is a total fall of $-0,982 \%$, which is larger than in the former simulation. However, the type of adjustment is totally different. Now, the losers are the non-tradable sectors due to a fall of investment and of household consumption of service goods. Construction and Family Services are the activities with main decreases in employment.

On the other hand, the results for the traditional tradable sectors are no longer negative. The main reason is that exports will increase to compensate the decrease of capital inflows. Anyway, the most benefited sectors still would be the modern tradable protected by higher tariffs, such as chemical and automobile industry.

29 Not considering the effects of the non-tariff barriers changes.

30 Comparing with the former simulation, we have export increases instead of reduction. 
Independently of the economic sectors, the employment reduction is more concentrated on informal and unskilled workers confirming the unequal tendency of jobs reduction.

TABLE 6 - SIMULATING AN IMPORT TARIFFS RISE AND CAPITAL INFLOW REDUCTION

\begin{tabular}{|c|c|c|c|c|c|c|c|}
\hline \multicolumn{8}{|c|}{ Percentage Change in the Average Wage } \\
\hline & Worker 1 & Worker 2 & Worker 3 & Worker 4 & Worker 5 & Worker 6 & Worker 7 \\
\hline Total & $-1,229$ & $-1,587$ & $-0,972$ & $-1,639$ & $-0,681$ & $-1,696$ & $-1,684$ \\
\hline
\end{tabular}

Note: 11-unskilled informal; 12-skilled informal; 13-formal with low skill; 14-formal with average skill; 15- formal with highly skilled; 16- low skilled public servant; 17- highly skilled public servant.

Analyzing Table 6, we realize that there are a generalized loss of real wages. As in the previous simulation, the higher reduction of public servants' remuneration occurs because their employment is fixed in the model and so, the total effect goes to salaries. The differentiated impact among labor groups seems to compensate the loss of quantities (jobs). Anyway, it is evident that a policy to reduce the trade deficit, through import tariffs, causes a reduction at total labor expenditure.

Looking to labor groups in the private sector, we see that the major decreases are for formal with average skills (type 4) and skilled informal (type 2). The reason for this differentiation can be the effect of the wage curve that arbitrates between "loss of jobs" or "loss of real wages".

TABLE 7 - SIMULATING AN IMPORT TARIFFS RISE AND CAPITAL INFLOW REDUCTION

\begin{tabular}{cccccccc}
\hline \multicolumn{7}{c}{ Percentage Change in Household Income } \\
\hline Family 1 & Family 2 & Family 3 & Family 4 & Family 5 & Family 6 & Family 7 & Family 8 \\
\hline$-1,791$ & $-0,553$ & $-1,866$ & $-1,522$ & $-1,268$ & $-1,413$ & $-1,176$ & $-1,176$ \\
\hline
\end{tabular}

Note: $\mathrm{fl}$ - poor urban families headed by active individuals, $\mathrm{f} 2$ - poor urban families headed by nonactive individuals, $\mathrm{f} 3$ - poor rural families, $\mathrm{f} 4$ - urban families with low average income, $\mathrm{f5}$ urban families with average income, f6 - rural families with average income, f7 - families with high average income, f8 - families with high income.

The analysis of household income allows a better identification of which group is more affected by including all the effects in quantities and prices together. The main losers 
are the rural poor (type 3) and urban poor (type 1) families. On the other hand, the households with smaller losses are the non-active urban poor (type 2) and high-income (type 8) families. These two groups share an important characteristic: their incomes have a significant participation of non labor income, such as social security benefits for the first and civil servants social security benefits and capital interest for the second. ${ }^{31}$

\subsection{Sensitivity Analysis}

Finally, to test our results against important model parameters, we have performed a simulation combining the tariff rise with a $10 \%$ increase of CES import elasticities for all tradable sectors. Appendix 2, reported results replicate Tables 3 and 4 (previously presented), with and without elasticities changes, showing that the resulting magnitudes are sensible for these parameters but they do not change the directions and hierarchy of results among labor groups.

\section{CONCLUSION}

In this paper, we have investigated the effect of a change in the external policy on some indicators related to social welfare. More precisely, we have estimated how the structures of wages and employment, as well as the distribution of household income would react to an import tariff rise back to the levels observed in the Brazilian economy in 1990. Also, these reactions were investigated in an environment characterized by tariffs rise together with a decline in capital inflows.

Despite the modest aggregate effects for employment and wages, the reactions are different for each type of worker. The effects on the employment structure have been slightly more pronounced. The tradable sectors that employ unskilled workers more intensively presented falls in employment in our import tariff rise simulation.

When we implemented the second simulation, with reduction of capital inflow, the significance of results were increased, reinforcing the reduction of total income amount that was appropriated for all different group of workers.

From a distributive point of view, two hypotheses deserve attention. Concerning the wage structure, we have imposed rigidity in the wage differentials by sector of activity. Therefore, one would expect greater reactions in the employment levels rather than in the wages.

31 Again we emphasize that the same indexed factor is used to correct all types of income flows. 
In relation to the formation of the household income, recall that we have fully indexed all types of transfers in a single way (with the model's price index), which implies in the impossibility of capturing all the effects arising from distributive conflicts. This fact poses an important question for CGE models aimed at measuring the effects on poverty and inequality: how to reconcile the general equilibrium theoretical structure and its respective properties with model specifications concerned with the distributive conflicts that exist in the flow of income transfers, in situations where changes in relative prices take place.

An alternative to this "full indexation" would be to attribute different monetary correction indexes to the various transfers existing in the model. In principle, the different family groups have bargaining power on the price index level to be applied on the transfers from Government and on the distribution of these transfers among the family groups. For example, a specific family group can be able of having its transfers being multiplied by a price index higher than the general price index of the economy and/or increasing its share in the distribution of these resources over the family groups.

In the model, we assume that the family groups cannot affect either the magnitude of the price index applied to their transfers or their shares in the distribution of resources transferred by the Government. Actually, the incorporation of the above-referred bargaining powers would require the full modeling of the distributive conflicts, which is beyond the objectives of this paper but will considered as a future direction of research. Even though, our guess is that this is not an easy task to be implemented without taking arbitrary assumptions and/or violating one of the principles of applied general equilibrium modeling.

This aspect is very important when we analyze the simulation effects for all household types. Despite the welfare losses for all families, it is evident that the major effects are for rural and urban poor families. Recall that we simulated a "partial" closure of the Brazilian economy and, in this sense, the simulation results can be interpreted as being the families' welfare changes in the absence of the external liberalization process. Then, the main losers in the simulation can be viewed as the groups that have actually benefited more by this process, $\mathrm{i}$ e, the results reported here can be interpreted as indicating that this process would have had a progressive distributive impact in Brazil.

Despite the differences, the general results reported here seem to be in accordance with the general findings reported by Barros et al. (2000), Hertel et al. (2003) and Harrison et al. $(2003) .{ }^{32}$

32 Even in this case, the results could not be directly compared due to the differences in the model closures and databases. Also, differences in model structures would affect the results, especially those related to the labor market assumptions, types of workers, classification of households and the matrix that maps the income flows from institutions to families. 
The only poor family that avoids this process would be a family headed by non-active person. At this point, we are back to the former question: would the inactive dependent of public social security system have the same income correction of the financial assets held by the highest income families? The most probable answer is no, which will reinforce the process of income concentration induced by the simulations.

Finally, we have emphasized that our results are based on CGE model that is not dynamic and, thus, it does not allow the incorporation of the future path of investments and of the pattern of capital accumulation. Furthermore, the empirical literature has shown that tariff policies affect total factor productivity. Nevertheless, our position is that these effects would sustain the direction of the results that we have obtained, probably, with larger magnitudes.

\section{BIBLIOGRAPHICAL REFERENCES}

Armington, Paul. A theory of demand for products distinguished by place of production. IMF Staff Papers, v. 16, p. 157-178, 1969.

Barros, R. P. de; Corseuil, C. H.; Cury, S. Abertura comercial e liberalização do fluxo de capitais no Brasil: impactos sobre a pobreza e a desigualdade. In: Henriques, R. (org.), Desigualdade e pobreza no Brasil. Rio de Janeiro: IPEA, 2000, p. 271-298.

- Salário mínimo e pobreza: uma abordagem de equilíbrio geral. Pesquisa e Planejamento Econômico, Rio de Janeiro: IPEA, v. 30, n. 2, p. 157-182, 2000a.

Blanchflower, D. G.; Oswald, A. J. The wage curve. Scandinavian Journal of Economics, v. 92, p. 215-235, 1990.

. The wage curve. Cambridge, Massachusetts: MIT Press, 1994, 493 p.

Bonelli, R.; Hahn, L. Resenha dos estudos recentes sobre relações comerciais brasileiras. Rio de Janeiro: IPEA, Texto para Discussão 708, 2000.

Bourguignon, F.; Silva, L. P. da; Stern, N. Evaluating the poverty impact of economic policies. World Bank, draft, March 2002.

Bovenberg, A. L.; Graafland, J. J.; Ruud, A de Mooij. Tax reform and the Dutch labor market: an applied general equilibrium approach. Journal of Public Economics, Elsevier, v. 78, n. 1, 10, p. 193-214, 2000.

Castilho, M. R. Impactos de acordos comerciais sobre a economia brasileira: resenha dos trabalhos recentes. Rio de Janeiro: IPEA, Texto para Discussão 936, 2002.

Cury, S. Modelo de equilibrio geval para simulação de politicas de distribuição de renda e crescimento no Brasil. 1998. 176p. Tese (Doutorado), Departamento de Economia, Fundação Getúlio Vargas, São Paulo. 
Devarajan, S.; Lewis, J.; Robinson, S. From stylized to applied models: building multisector CGE models for models for policy analysis. USA: University of California at Berkeley, Department of Agriculture and Resources Economics, Working Paper 616, 1991.

Devarajan, S.; Hossain, S. I. The combined incidence of taxes and public expenditure in the Philippines. World Development, v. 26, n. 6, 1998.

Ferguson, L. et al. The impact of the Barnett formula on the Scottish economy: a general equilibrium analysis. Glasgow, Scotland: Department of Economics, University of Strathclyde, Discussion Paper 03-04, 2003.

Ginsburgh, V.; Keyzer, M. The structure of applied general equilibrium models. Cambridge, Massachusetts: MIT PRESS. 1997, 555p.

Haddad, E. A.; Domingues, E P.; Perobelli, F S. Regional effects of alternative strategies for economic integration: the case of Brazil. Joumal of Policy Modeling, v. 24, p.453-482, 2002.

Harrison, G. W. et al. Políticas de comércio regionais, multilaterais e unilaterais do Mercosul para o crescimento econômico e a redução da pobreza no Brasil. Pesquisa e Planejamento Econômico, Rio de Janeiro: IPEA, v. 33, n. 1, p. 1-60, 2003.

Hertel, T. W. et al. Multilateral trade liberalization and poverty in Brazil and Chile. Économie internationale, 94-95, p. 201-234, 2003.

Holand-Holst, D. W.; Reinert, K. A.; Shiells, C. R. A general equilibrium analysis of North American economic integration. In: Modeling trade policy: applied general equilibrium assessments of North American free trade. New York: Cambridge University Press, p. 47-82, 1994.

Kume, H.; Piani, G.; Souza, C. F. A politica brasileira de importação no periodo 198798: descrição e avaliação. Rio de Janeiro: IPEA, 2000. Mimeografado.

Pinheiro, A. C.; Ramos, L. A. Inter-industry wage differentials and earnings inequality in Brazil. Estúdios de Economia, v. 21, p. 79-111, 1995.

Reis, M. Mudanças na estrutura da demanda por trabalho qualificado e na composição da oferta e seus impactos sobre desemprego. Rio de Janeiro: PUC-Rio, 2002. Mimeografado.

Tourinho, O.; Kume, H.; Pedroso, A. C. Elasticidades de Armington para o Brasil: 1986-2001. Rio de Janeiro: IPEA, Texto para Discussão 901, 2002. 
APPENDIX 1 - RESULTS ASSOCIATED WITH A CHANGE OF 100\% IN THE EXCHANGE RATE

TABLE A1.1 - EARNINGS RESPONSE TO AN EXCHANGE RATE APPRECIATION OF 100\%: PERCENTAGE CHANGE IN ABSOLUTE VALUES

\begin{tabular}{cccc}
\hline & Employment & Nominal Wages & Real Wages \\
\hline Worker 1 & $-1,11 \mathrm{E}-11$ & 100,00 & $8,26 \mathrm{E}-12$ \\
Worker 2 & $7,33 \mathrm{E}-13$ & 100,00 & $2,22 \mathrm{E}-14$ \\
Worker 3 & $9,99 \mathrm{E}-13$ & 100,00 & $-8,55 \mathrm{E}-13$ \\
Worker 4 & $-9,99 \mathrm{E}-14$ & 100,00 & $5,77 \mathrm{E}-13$ \\
Worker 5 & $-1,11 \mathrm{E}-14$ & 100,00 & $2,44 \mathrm{E}-13$ \\
Worker 6 & $2,22 \mathrm{E}-14$ & 100,00 & $8,88 \mathrm{E}-14$ \\
Worker 7 & $-1,11 \mathrm{E}-14$ & 100,00 & $1,55 \mathrm{E}-13$ \\
\hline
\end{tabular}

TABLE A 1.2 - EARNINGS RESPONSE TO AN EXCHANGE RATE APPRECIATION OF 100\%: PERCENTAGE CHANGE IN ABSOLUTE VALUES

\begin{tabular}{lcc}
\hline & Gross Income & Net Income \\
\hline Gov & 100,00 & \\
Large Firm & 100,00 & 100,00 \\
Small Firm & 100,00 & 100,00 \\
Household 1 & 100,00 & 100,00 \\
Household 2 & 100,00 & 100,00 \\
Household 3 & 100,00 & 100,00 \\
Household 4 & 100,00 & 100,00 \\
Household 5 & 100,00 & 100,00 \\
Household 6 & 100,00 & 100,00 \\
Household 7 & 100,00 & 100,00 \\
Household 8 & 100,00 & 100,00 \\
\hline
\end{tabular}


APPENDIX 2 - SENSITIVITY ANALYSIS: COMPARISON OF RESULTS BETWEEN THE IMPORT TARIFF INCREASE WITHOUT AND WITH A 10\% INCREASE OF CES IMPORT ELASTICITIES

To test our results against important model parameters, we perform a simulation combining the tariff removal with a $10 \%$ increase of the CES import elasticities for all tradable sectors. The impacts of these combined simulation are presented in the second lines of Tables A2.1 and A2.2 below, while in the first lines are reported the original (tariffs increase) impacts.

TABLE A2.1 - SIMULATING IMPORT TARIFFS RISE WITHOUT AND WITH ELASTICITIES CHANGE

\begin{tabular}{lccccccc}
\hline \multicolumn{7}{c}{ Percentage Change in the Average Wage } & \\
\hline & Worker 1 & Worker 2 & Worker 3 & Worker 4 & Worker 5 & Worker 6 & Worker 7 \\
\hline Tariffs & $-0,673$ & $-0,522$ & $-0,483$ & $-0,724$ & $-0,007$ & $-0,587$ & $-0,76$ \\
$\begin{array}{l}\text { Tariffs+10\% CES } \\
\text { elasticies }\end{array}$ & -0.976 & -0.804 & -0.661 & -1.021 & -0.214 & -0.930 & $-0,901$ \\
\hline
\end{tabular}

Note: 11-unskilled informal; 12-skilled informal; 13-formal with low skill; 14-formal with average skill; 15- formal with highly skilled; 16- low skilled public servant; 17- highly skilled public servant.

Firstly, Table A2.1, above, replicates Table 3 (wage variations) and shows that the resulting magnitudes are sensible for these parameters but they do not change the directions and hierarchy of the results among labor groups. Thus, the highest variation among private groups occurs for the worker 4 (formal with average skills) and the lowest is related to the worker $\mathbf{5}$ (formal with high skill).

TABLE A2.2 - SIMULATING IMPORT TARIFFS RISE WITHOUT AND WITH ELASTICITIES CHANGE

\begin{tabular}{cccccccc}
\hline \multicolumn{7}{c}{ Percentage Change in the Household Income } \\
\hline Family 1 & Family 2 & Family 3 & Family 4 & Family 5 & Family 6 & Family 7 & Family 8 \\
\hline$-0,512$ & $-0,229$ & $-0,452$ & $-0,458$ & $-0,478$ & $-0,428$ & $-0,5$ & $-0,462$ \\
$-0,524$ & 0,003 & $-0,473$ & $-0,396$ & $-0,377$ & $-0,352$ & $-0,390$ & $-0,340$ \\
\hline
\end{tabular}

Note: $\mathrm{fl}$ - poor urban families headed by active individuals, $\mathrm{f} 2$ - poor urban families headed by nonactive individuals, f3 - poor rural families, f4 - urban families with low average income, f5 urban families with average income, f6 - rural families with average income, f7 - families with high average income, f8 - families with high income. 
Table A2.2 replicates Table 4 (household income variation) and shows that for the extreme value variations, results are similar to the wage changes. The family with the least variation in both experiment is family 2 (poor urban families headed by non-active individuals) and that with highest is family 1 (poor urban families headed by active individuals). But, among the intermediate variations there are slightly differences: now family 3 (rural poor) is worsening its position and the richest family 8 is better off. Our interpretation is that higher elasticities operates as higher price variations in both directions worsening the situation of rural sectors and improving the situations of households with considerable participation of income that does not come from production.

Thus, the sensitivity analysis reinforce our conclusions about income distribution changes and most important of all, highlight our interpretation about the role played by imposition of homogeneous property at CGE analysis.

The authors thank the valuable comments and suggestions from Geoffrey Hewings, the participants of the International Conference on Input-Output and General Equilibrium: Data, Modeling, and Policy Analysis (Brussels, Sept. 2004) and an anonymous referee.

Contacting author FGV-EAESP - Departamento de Economia - Av. 9 de Julho, 2029 - Bela Vista - São Paulo - SP - CEP 01313-902.

E-mails: sacury@terra.com.br; allexandro_coelho@yahoo.com.br; kiko@ipea.gov.br.

Allexandro Mori Coelho acknowledges the support from Regional Economics Applications Laboratory (REAL), University of Illinois at Urbana-Champaign, USA.

(Recebido em dezembro de 2004. Aceito para publicação em agosto de 2005). 